\title{
A PROBABILISTIC ANALYSIS OF LENGTH OF STAY IN HOSPITAL
}

\author{
Hidehiko TANIMURA*, Member of A.I.J.
}

\section{INTRODUCTION}

\subsection{Significance of Length of Stay in Hospital Planning}

Throughout the world of today, an adequate provision of health services has been recognized as one rof the essential community responsibilities. An emerging concept of a hospital as the center of the comprehensive health service system in the community has been displacing the old idea of a hospital as an institution specialized in care of the sick. ${ }^{1 .}$ The change calls for a critical review of various indices used in the assessment of hospital performance. This is an essential step toward the rational planning of hospital buildings and management.

One of such indices is the length of stay in hospital. The index indicates the period in hospital per patient admitted, usually in terms of days. Both the day of admission and the day of dischage are counted according to the definition set by the Ministry of Welfare in Japan. The length of stay is related to the number of hospital beds in a manner expressed by the equation,

$$
B=\frac{A \times L}{u} \text {. }
$$

where $B=$ number of hospital beds

$A=$ average number of admission per day

$L=$ average length of stay in days and

$u=$ bed-occupancy ratio.

Two points should be made on this equation. First, given an average number of admissions per day, a required number of hospital beds in the community changes in direct proportion to the average length of stay and in inverse proportion to the bed-occupancy ratio. This aspect alone would be enough to justify indepth studies of the length of stay in hospital. Second, the bed-occupancy ratio, which is often taken as an index of hospital efficiency, may be altered by the changing length of stay. If there is a big variation in the occurrence of cases requiring hospitalization, the bed-occupancy ratio must be kept low to make emergency admissions possible. Thus, a true assessment of hospital efficiency cannot be made without a full knowledge about the length of stay.

The significance of the length of stay as an index of hospital performance goes beyond these two points. A hospital in patient service may be considered as a service process in the theory of queues in operations research. The length of stay corresponds to the duration of service or simply service time. A knowledge and understanding of the distribution of service time is a necessary prerequisite for the application of the theory to hospital management.

The index has many implications also for hospital architecture. For example, certain facilities in the hospital, such as diagnostic facilities, should be given a cpapacity in proportion to the number of new admissions rather than to the number of beds. A reduction in the length of stay is likely to increase the demand for such facilities, other things being equal.

\subsection{Study objectives and method}

The primary objective of the study is to develop a practical tool for the investigation into the

* M.A.I.J., M.A.T.P.I.C., Assistant Professor, Department of City Planning, Unversity of Manitoba.

1. R. Llewelyn-Davies, Baron and H.M.C. Macaulay. Hospital Planning and Administration, (W.H.O : Geneva, 1966) Monograph series No. 54, pp. 23-24. 
behaviour of the length of stay in hospital for the purposes mentioned earlier. The pioneering work was undertaken by professor Y. Yoshitake of the University of Tokyo and reported by him as early as. in $1960 .^{2}$. He found that the distribution curve of the length of stay in hospital could be obtained by differentiating the distribution function of "time after admission" of patients currently hospitalized on. a randomly selected survey day. He also found that the latter function could be approximated by a sum of two exponential functions each with a different mean. Two shortcomings of this method may be pointed out. One is the influence of fluctuations in admissions and the other is a need for a. subjective judgment in determining parameters of the mixed exponential function. This present study is an attempt to improve upon the original method by formulating a model on the theory of probability and also by eliminating the element of arbitrariness from the process of curve fitting as much as. feasible. The model will be tested against two sets of observed data for evaluation.

\section{MODELS}

\subsection{Preliminaries}

A hospital stay is a service process whereby a patient is admitted, receives services, and is eventually discharged. In this process, each patient has his characteristic random variable, $l$, called his length of stay. For a population of patients, we then define a probability density function of the length of: stay by the equation,

$$
f(x)=\lim _{\Delta x \rightarrow 0+} \frac{\operatorname{prob}(x>l \leq x+\Delta x)}{\Delta x}
$$

with

$$
\int_{0}^{\infty} f(x) d x=1
$$

The function is defined zero for negative $x$. The quantity $f(x)$ is a rate because its dimensions are. probability divided by time. If we imagine a group of patients all admitted at the same time and discharged at defferent times, $f(x)$ would measure the mean rate at which their hospital stay is ending. at time $x$.

As Yoshitake pointed out in his paper, however, a direct observation of the completed length of: stay requires a collection of historical data over a long period of time. On the other hand, it is relatively. easy to obtain the dates of admission of the patients staying in hospital on a particular survey day.. It is also easy to obtain the past record of the number of admissions per day or some other time unit. A quantity obtained by dividing the number of patients admitted during a certain period in the past and still hospitalized on a survey day by the total number of new admissions during the corresponding. period indicates the probability that the length of stay of this group of patients will be longer than the period they already spent in hospital. This quantity $F(x)$ is related to $f(x)$ by the equation,

$$
F(x)=\int_{x}^{\infty} f(x) d x
$$

It should be noted here that the shape of function $F(x)$ should be exactly the same as the fre-quency distribution of time after admission of the current patients in Yoshitake's paper, although dimensions are different, provided that there is no fluctuation in the number of admissions over time. However, there are occasions that this assumption may likely lead to an erroneous conclusion. One is. the case of expanding hospitals with relatively long average length of stay, such as an expanding. mental hospital. The simple frequency distribution of the time after admission is likely to overrepresent recent patients and distort the reality in this case. Another case is concerned with hospital services: which experience a wide variation in admissions, such as obstetrics. The proposed probabilistic formulation permits us to eliminate these possible distortions by removing the influence of fluctuations in admissions.

2. Yasumi Yoshitake. "On the length of Stay in Hospital Planning", Transactions of the Architectural Institute of Japan, No. 66, October 1960 and also "Planning of Long-term Care Medical Facilities", Transactions of the Architectural Institute of Japan, No. 71, April 1962. 
In this paper, following the convention of the probability theory, we call $f(x)$ a probability density function and distinguish it from $F(x)$, a probability distribution function. The average length of stay, $L$, is calculated by the equation,

$$
L=\int_{0}^{\infty} x f(x) d x=\int_{0}^{\infty} F(x) d x .
$$

In other words, the area under curve $F(x)$ in Figure 1 turns out to equal the average length of stay in hospital. ${ }^{3}$. This relation holds regardless of the type of function. This definition of the average length of stay seems to be the most appropriate one particularly when the institution is undergoing a rapid expansion or contraction.

At this moment, it should be noted that $f(x)$ and $F(x)$ are mathematically equivalent. Therefore, any information concerning the length of stay may be obtained from either of the two functions. In fact, it is usually more convenient to work with $F(x)$ than $f(x)$ in the application of the theory of queues. This is another point in favour of the adoption of as the basis for the investigation into the length of stay. Our next step is to analyse

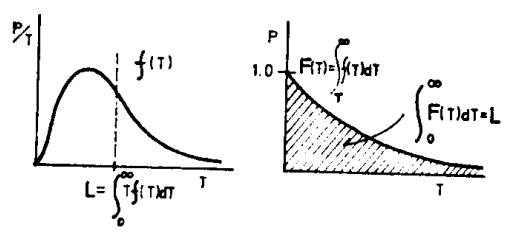

Fig.-I Density and Distribution Functions the actual from of $F(x)$ to gain insight into the operation of the service process.

\subsection{Exponential Model}

If the chance of occurrence of discharge of a patient is independent of the time he already spent in hospital, the theory of probability indicates that the probability density function of the length of stay is exponential, that is,

$$
f(x)=\lambda e^{-\lambda x}
$$

and therefore

$$
F(x)=\int_{x}^{\infty} \lambda e^{-\lambda x}=e^{-\lambda x}
$$

where $\lambda$ denotes the probability of immediate discharge of the patient, called the rate parameter. The average length of stay in this case turns out to equal the reciprocal of the parameter $\lambda$.

Because of this normative characteristic of the exponential model, it is a good practice to plot the observed curve of $F(x)$ on a semi-logarithmic scale. A straight line corresponding to the average length of stay calculated by equation (5) may then be compared to the observed curve. If the two curves show a good fit, the service process can be assumed to be an exponential service channel. In the exponential distribution, the coefficient of variability, that is, a ratio of the standard deviation to the mean, should be unity.

\subsection{Mixed-exponential Model}

There are cases where the distribution shows a greater variability than the exponential channel, that is, its coefficient of variability is greater than unity. One interpretation of these cases is that the group of patients are composed of two or more homogenious sub-groups, each having an exponential distribution with a different mean. Its distribution curve shows a concave shape on the semi-logarithmic scale. This is exactly what Professor Yoshitake found applicable to many length of stay distributions. ${ }^{4}$ As he pointed out, it is usually sufficient for practical purposes to assume two such homogenious subgroups, one with a short mean value and the other with a relatively long mean value.

We can visualize the mixed exponential model as an arrangement in parallel of channels with different service times. The theory of queues shows that a greater efficiency is obtained by creating two separate physical facilities for the two groups, if it is possible to classify the two groups in advance or shortly after admission.

The mixed exponential model involves three parameters; two mean values and a ratio between the

3. For proof, see Philip M. Morse, Queues, Inventories and Maintenance. (John Wiley and Sons : New York, 1958). p. 9

4. Yoshitake, op. cit. 
number of patients in each group. Two obvious methods are, first, curve-fitting by hand and, second, least square approximation. The former was described in Professor Yoshitake's paper in detail and will not be discussed in this paper further. The latter is theoretically feasible by the application of the Gauss-Newton iteration method. ${ }^{5}$. However, the length of stay data is usually truncated or not very reliable due to the paucity of samples beyond a certain time span. The least square method does. not necessarily yield a satisfactory solution in these cases. Thus in this paper, two other practical alternatives are proposed and discussed below.

a) Mean-variance Method

This method calculates the three parameters mentioned above from the mean of $f(x)$, and the mean and variance of $F(x)$. Suppose that the probability density function $f(x)$ is expressed by the equation,

$$
f(x)=\theta \lambda_{1} e^{-\lambda_{1} x}+(1-\theta) \lambda_{2} e^{-\lambda_{2} x} \quad \lambda_{1}>\lambda_{2} \cdots
$$

and the corresponding distribution function by the equation,

$$
F(x)=\theta e^{-\lambda_{1} x}+(1-\theta) e^{-\lambda_{2} x}
$$

The Laplace transforms of these two functions are respectively,

$$
f^{*}(s)=\theta\left(\frac{\lambda_{1}}{\lambda_{1}+s}\right)+(1-\theta)\left(\frac{\lambda_{2}}{\lambda_{2}+s}\right)
$$

and

$$
F^{*}(s)=\frac{\theta}{\lambda_{1}+s}+\frac{1-\theta}{\lambda_{2}+s}
$$

Except for the sign of $s$, the Laplace transform is the moment generating function. Thus by the Taylor expansion of (10) and (11), the mean of $f(x)$ and the mean and variance of $F(x), M$ and $V$, are derived as follows :

$$
\begin{aligned}
& L=\frac{\theta}{\lambda_{1}}+\frac{1-\theta}{\lambda_{2}} \\
& M=\frac{1}{L}\left(\frac{\theta}{\lambda^{1}}+\frac{1-\theta}{\lambda_{2}}\right) \\
& V=\frac{2}{L}\left(\frac{\theta}{\lambda_{1}{ }^{3}}+\frac{1-\theta}{\lambda_{2}{ }^{3}}\right)-M^{2}
\end{aligned}
$$

The simultaneous equations (12), (13) and (14) can be solved explicitly. First we substitute $1 / \lambda_{1}$ with $p$, and $1 / \lambda_{2}$ with $q$ and transform these equations to

$$
\begin{aligned}
& a=\theta(p-q)+q=L \\
& b=\theta\left(p^{2}-q^{2}\right)+q^{2}=L M \ldots \ldots \ldots \ldots \ldots \ldots \ldots \ldots . . . \\
& c=\theta\left(p^{3}-q^{3}\right)+q^{3}=\frac{L}{2}\left(M^{2}+V\right)
\end{aligned}
$$

Writing $p+q=u$, and $p q=v$, these equations can be solved, giving,

$$
\begin{aligned}
& u=\frac{c-a b}{b-a^{2}}=\frac{M^{2}+V-2 L M}{2(M-L)} \\
& v=\frac{a c-b^{2}}{b-a^{2}}=\frac{L\left(V-M^{2}\right)}{2(M-L)}
\end{aligned}
$$

We then derive the values $p$ and $q$ by solving the quadratic equation

$$
X^{2}-u X+v=0
$$

The value of $\theta$ is then obtained by equation (15). This method yields uniquely the values for thethree parameters of distribution by step-by-step calculation.

b) Percentage-point Method

The above mean-variance method is not applicable when the available data is severely truncated at the upper tail. For these cases, the percentage-point method produces a better result, although the solution may not be unique depending on the choice of points used for estimation. ${ }^{6}$. In this method

5. H.O. Hartley, "The Modified Gauss-Newton Method for Fitting of Non-Linear Regression Functions by Least Squires". Technometrics, Vol. 3, No. 2, May 1961.

6. D.J. Bartholomew, "Note on the Measurement and Prediction of Labor Turnover", Journal of the Royal Statistical Society, A. 122, 1959. pp. 232-239. 
we first obtain from the observed data the values of $F(x)$ at three points $t_{1}, t_{2}, t_{3}$ so that

$$
t_{2}=2 t_{1}, t_{3}=6 t_{1}
$$

Let

$$
p=e^{-\lambda_{1} t_{1}}, q=e^{-\lambda_{2} t_{1}}
$$

then we have the equations

$$
\begin{aligned}
& F\left(t_{1}\right)=\theta(p-q)+q \\
& F\left(t_{2}\right)=\theta\left(p^{2}-q^{2}\right)+q^{2} \\
& F\left(t_{3}\right)=\theta\left(p^{6}-q^{6}\right)+q^{6}
\end{aligned}
$$

Writing $p+q=u$ and $p q=v$ these equations can be solved explicitly, giving

$$
\begin{aligned}
& \theta=\frac{F\left(t_{1}\right)-q}{p-q} \ldots \ldots \ldots \ldots \ldots \ldots \ldots \ldots \ldots \ldots \ldots \ldots \ldots \ldots \ldots \ldots \ldots \ldots \ldots \ldots \ldots \ldots \ldots \ldots \ldots \ldots \ldots \ldots \ldots \ldots \ldots \\
& v=F\left(t_{1}\right) u-F\left(t_{2}\right) \\
& u^{4}-2 F\left(t_{1}\right) u^{3}+3 F\left(t^{2}\right) u^{2}=\frac{F\left(t_{3}\right)-F\left(t_{2}\right)^{3}}{F\left(t_{2}\right)-F\left(t_{1}\right)^{2}}
\end{aligned}
$$

Equation (27) can be solved by the Newton-Raphson method starting with unity for a value of $u$. In our experience, the best result is obtained when $t_{1}$ is taken in the neighborhood of the average length of stay. In this respect, it is suggested here that the data should cover the range at least six times longer than the expected average length of stay. The third point need not be at six times of $t_{1}$, but any integer $k=3,4,5$, times $t_{1}$ with a corresponding change in equation (27).

\subsection{Erlangian Model}

In cases where the coefficient of variability is less than unity, that is, the distribution is less than pure random, Erlangian distributions often prove to be satisfactory. We can visualize the Erlangian model as an arrangement in series of exponential channels of identical means. The number of phases or channels in series is usually denoted by $k$ and determines the shape of distributions curve. The Laplace transform, $f(x)$ and $F(x)$ of Erlangian distributions are as follows,

$$
\begin{aligned}
& f^{*}(s)=\left(\frac{\rho}{\rho+s}\right)^{k} \\
& f(x) \rho(\rho x)^{k-1} \frac{e^{-\rho x}}{(k-1) !} \quad k=1,2,3, \cdots \quad r=0,1,2, \cdots \\
& F(x)=\sum_{r=0}^{k-1} \frac{e^{-\rho x}(\rho x)^{r}}{r !}
\end{aligned}
$$

where $\rho$ is the rate parameter of the exponential curve of each of the phases. The cohice of $k$ can be made by comparing successively the theoretical $F(x)$ curves calculated for various integer values $k$ $=1,2,3, \cdots$ with the observed curve of $F(x)$. The parameter $\rho$ then is obtained by multiplying the reciprocal of the total length of stay by $k$, that is

$$
\rho=\frac{k}{L}
$$

The standard deviation and the coefficient of variability of this distribution are

$$
\text { S.D. }=\frac{\sqrt{R}}{\rho}, \quad \text { C.V. }=\frac{1}{\sqrt{R}}
$$

\subsection{Markov Process Model}

So far we have considered only the arrangement of channels in parallel, that is, mixed exponential, and the one in series, that is, Erlangian. The physical interpretation of these arrangements are shown in Figure II. A more complex model of any combination of these arrangements can be made by using the theory of Markov process. Loosely speaking, there are two conditions for its application. First, the definition of phases or steps should be mutually exclusive and unique. In other words, at any particular moment, a patient must occupy one and only one of these or states as they are called in the theory of Markov process. Second, the transition probabilities governing the change are determined entirely by the state occupied at the moment and not by his previous history. These two conditions are implicit also in the three types of models we have discussed. 
A general formuration of the theory of Markov process is quite complex and cannot be made in this short paper ${ }^{7}$. We consider therefore a special combination of mixed-exponential and Erlangian, depicted as d) in Figure II. This is a four state Markov process in continuous time.

Suppose at any moment a patient can be uniquely classified to one of the following states:

State $1:$ Acute treatment stage subsequent to admission,

State $2:$ Short-term recuperative stage after treatment,

State 3 : Long-term (chronic) recuperative stage after treatment,

State 4 : Discharged either by recovery or by death.

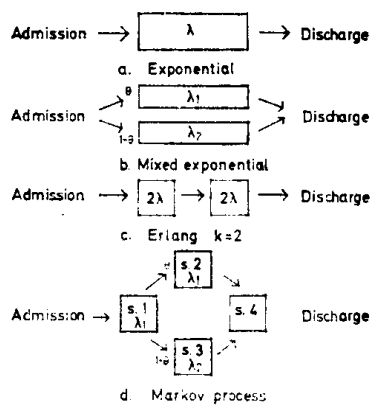

Fig.-II Service Channel Arrangement If we denote the transition rate from State $i$ to State $j$ by $r_{i j}$ the process is defined by the transition rate matrix $\boldsymbol{Q}$ such that

$$
\boldsymbol{Q}=\left(\begin{array}{llll}
r_{11} & r_{12} & r_{13} & r_{14} \\
r_{21} & r_{22} & r_{23} & r_{24} \\
r_{31} & r_{32} & r_{33} & r_{34} \\
r_{41} & r_{42} & r_{43} & r_{44}
\end{array}\right)
$$

For the sake of simplicity, we assume that certain transitions cannot occur and use the following rate matrix for our study. It is reminiscent of the Erlangian model that the elements $r_{11}$ and $r_{22}$ are assumed to be equal.

$$
\boldsymbol{Q}=\left(\begin{array}{cccc}
-\lambda_{1} & \theta \lambda_{1} & (1-\theta) \lambda_{1} & 0 \\
0 & -\lambda_{1} & 0 & \lambda_{1} \\
0 & 0 & -\lambda_{2} & \lambda_{2} \\
0 & 0 & 0 & 0
\end{array}\right) .
$$

The duration of time patients spend from the entrance to State 1 to the entrance to State 4 is what we call the length of stay. This quantity is usually known as the first passage time in the theory of Markov process. In this model, there are two possible routes to proceed from State 1 to State 4. The route passing through State 2 can be considered a special Erlangian channel with $k=2$ having the Laplace transform of the probability density function of repuired passage time,

$$
f_{1}^{*}(s)=\left(\frac{\lambda_{1}}{\lambda_{1}+s}\right)^{2}
$$

On the other hand, the other route through State 3 is a generalized Erlangian channel. The corresponding Laplace transform of density function is

$$
f_{2}^{*}(s)=\left(\frac{\lambda_{1}}{\lambda_{1}+s}\right)\left(\frac{\lambda_{2}}{\lambda_{2}+s}\right)
$$

Considering the ratio of these two groups of patients, we then have the Laplace transform of the density function of the total length of stay distribution in the form

$$
f^{*}(s)=\theta\left(\frac{\lambda_{1}}{\lambda_{1}+s}\right)^{2}+(1-\theta)\left(\frac{\lambda_{1}}{\lambda_{1}+s}\right)\left(\frac{\lambda_{2}}{\lambda_{2}+s}\right)
$$

On inversion, we obtain the density function and the distribution function of the length of stay such that

$$
\begin{aligned}
& f(x)=\theta \lambda_{1}^{2} x e^{-\lambda_{1} x}+(1-\theta) \frac{\lambda_{1} \lambda_{2}\left(e^{-\lambda_{2} x}-e^{-\lambda_{1} x}\right)}{\lambda_{1}-\lambda_{2}} \cdots \\
& F(x)=\theta\left(1+\lambda_{1} x\right) e^{-\lambda_{1} x}+(1-\theta) \frac{\lambda_{1} e^{-\lambda_{2} x}-\lambda_{2} e^{-\lambda_{1} x}}{\lambda_{1}-\lambda_{2}}
\end{aligned}
$$

The average length of stay of this model, obtained by integrating equation (39) expressed in the form

$$
L=\frac{2 \theta}{\lambda_{1}}+(1-\theta) \frac{\lambda_{1}+\lambda_{2}}{\lambda_{1} \lambda_{2}}
$$

In the following chapter, the models we have discussd will be tested against the actual data, with

7. For example, D.R. Cox and H.D. Miller. The Theory of Stochastic Processes. (Methuen: London, 1965). 
the exception of the exponential model. The estimation of the exponential model may be considered as a special case of the Erlangian model with $k=1$.

\section{APPLICATION}

\subsection{Mixed-exponential Model}

The two proposed methods of estimation have been used to test the mixed-exponential model against the data collected by Dr. Matsumoto. The data covers a total of 902 patients staying at three Workmen's Accident Compensation Hospitals, known as Rosai Byoin, in Tohoku, Kyushu and Ehime on a suvey day in $1966 .^{8}$. Since the information on the exact daily variation of the number of admissions was not included in the original study, the average number of 385 admissions per 50 days was used to calculate the observed values in Table I.

a) Mean-variance method

The average length of stay, mean and variance of the probability distribution function are calculated from the unpooled original data as follows:

$$
\begin{aligned}
& L=336.7, M=535.6, \\
& V=286,852.4 \ldots \ldots \ldots
\end{aligned}
$$

By using equations (15) to (20), the parameters of functions are calculated as shown in Table $I$.

\section{b) Percentage-Point Method}

From the pooled data as shown in the second column of Table I, three readings at 75,150 and 450 days are selected estimation. Thus it is not accidental that the calculated values at the three points are identical to the observed.

The results of the two methods are shown in Table I, together with the parameters given by Matsumoto in his paper for the purpose of comparison. Two sets of chi-square values are calculated from the result

to compare the degree of fitness of the three curves. It shold be noted that the statistical significance of these values is trivial as they are arbitrarily dependent upon the pooling intervals. They are used here just for comparative purposes only. The first set of chi-squares cover observations up to 350 days. It is clear the percentage point method yields better fit in this range, although its fitness at the upper tail declines. The second set of chi-squares cover the total observation. Here, the mean-variance method shows the best fit of the three. It is interesting to note the variation in the average length of stay of the long-term curve $1 / \lambda_{2}$, suggesting a danger of giving too much confidence to this parameter.

\subsection{Erlangian model}

This and Markov process models are tested against the data obtained from Tokyo T.B. Hospital.9. The data includes the dates of admission of 1,200 patients staying at the hospital on a survey day in

8. A. Matsumoto, "Length of Stay and the Ward Composition of Workmen's Accident Compensation Hospitals", Transactions of the Architectural Institute of Japan, No. 124, August 1966. The author owes gratitude to Dr. Matsumoto for the permission to use his data in this paper.

9. The author wishes to express gratitude for the kind cooperation from Professor Y. Yoshitake, Mr. Isomura, and $\mathrm{Mr}$. Yokobori with respect to the collection of the data. 


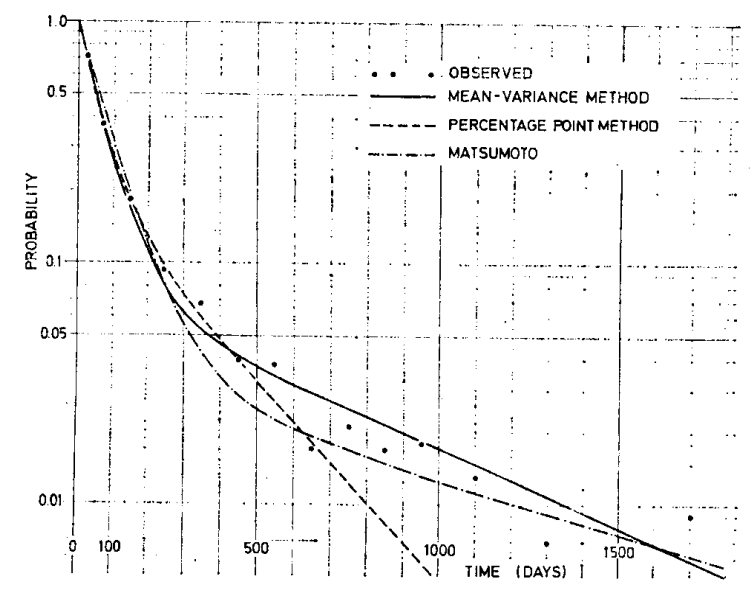

Fig.-III Mixed-exponential Probability Distributions

October 1970 and also the number of daily admissions as far back as October 1963. The admission figures beyond the date are assumed to be the average of 1963 and 1964, namely, 1,000 par annum.

The estimation of this model is relatively simple. First, the scatter diagram of the observed data is compared to specimen curves in a textbook and the value 2 is chosen as the best fit. The average length of stay is obtained by equation (5). As shown in Table II the upper tail of this model reduces too fast, suggesting the following Markov process model.

\subsection{Markov Process Model}

As the form the distribution function of this model as expressed by equations (38) and (39) is rather complex, we have proceeded with its estimution inductively relying on the findings of previous studies, and arrived at a satisfactory result. It was reported by Yoshitake that he identified two homogeneous groups of T.B. patients, one having an average length of stay of about a year and the other having the one of five years. ${ }^{10}$. Thus we have assigned the average of one year to the passage through State 2 and the one of five years to those who proceed through State 3 . Since in our model we assume that the length of stay in State 1 is the same as the one in State 2 , we have the average length of stay of half a year (180 days) for States 1 and 2, four and a half years (1,620 days) for State 3. The ratio parameter is then chosen to yield the observed average length of stay by using. equation (40). The curve obtained by the function with these parameters follows the observed distribution quite well, as shown in the last column of Table II, suggesting a closeness of this model to the reality.

The observed and calculated values of probabilities in Tables I and II are illustrated in semilogerithmic scale in Figures III and IV respectively.

\section{CONCLUSION}

To summarize, the study has found that

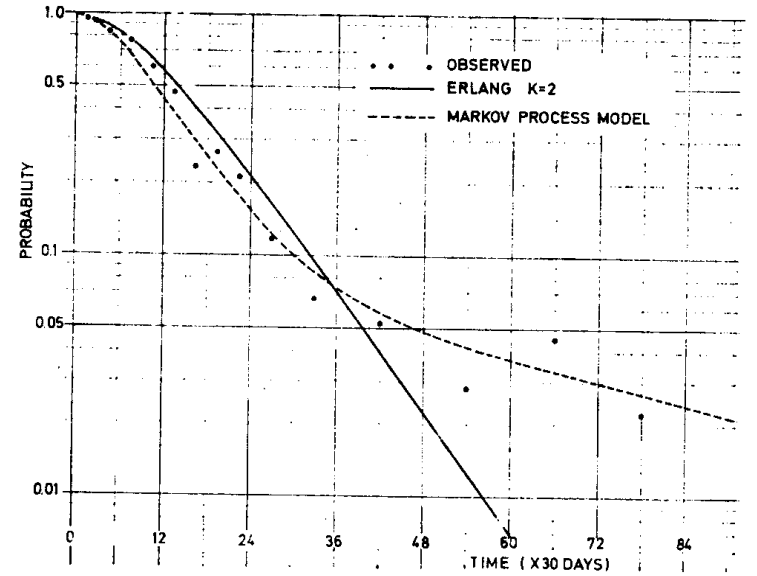

Fig.-IV Erlangian and Markov Process Probability Distributions

Table II Observed and Calculated Probability Distributions of Enlang $(k=2)$ and Markov Process models (Tokyo T.B. Hospital, 1970)

\begin{tabular}{|c|c|c|c|}
\hline $\begin{array}{c}\text { Time } \\
\text { (30 days) }\end{array}$ & Observed & $\begin{array}{l}\text { Erlangian } \\
\text { Model }\end{array}$ & $\begin{array}{c}\text { Markov Process } \\
\text { Model }\end{array}$ \\
\hline 1.5 & 0.981 & 0.986 & 0.976 \\
\hline 4.5 & 0.852 & 0.898 & 0.841 \\
\hline 7.5 & 0.786 & 0.774 & 0.674 \\
\hline 10.5 & 0.600 & 0.643 & 0.520 \\
\hline 13.5 & 0.474 & 0.521 & 0.394 \\
\hline 16.5 & 0.231 & 0.414 & 0.297 \\
\hline 19.5 & 0.268 & 0.324 & 0.225 \\
\hline 22.5 & 0.210 & 0.251 & 0.174 \\
\hline 27.0 & 0.116 & 0.168 & 0.122 \\
\hline 33.0 & 0.066 & 0.096 & 0.084 \\
\hline 42.0 & 0.052 & 0.040 & 0.058 \\
\hline 54.0 & 0.028 & 0.012 & 0.042 \\
\hline 66.0 & 0.045 & 0.003 & 0.033 \\
\hline 78.0 & 0.022 & 0.0009 & 0.026 \\
\hline 90.0 & 0.010 & 0.0003 & 0.021 \\
\hline 180.0 & 0.003 & - & 0.004 \\
\hline $\begin{array}{c}L \\
\text { (30 days) }\end{array}$ & 16.75 & 16.75 & 16.75 \\
\hline Parameters & & $\begin{aligned} k & =2 \\
1 / \rho & =8.375\end{aligned}$ & $\begin{aligned} \theta & =0.901 \\
1 / \lambda_{1} & =6.0 \\
1 / \lambda_{2} & =54.0\end{aligned}$ \\
\hline $\begin{array}{l}\text { Chi-squares } \\
\text { up to } 22.5 \\
\text { Total }\end{array}$ & - & $\begin{array}{r}107.0 \\
\infty\end{array}$ & $\begin{array}{l}77.6 \\
98.0\end{array}$ \\
\hline
\end{tabular}

10. Yoshitake, op. cit. 
a) The frequency distribution of "time after admission" can be regarded as the probability distribution function with a slight modification in data collection based on a probabilistic interpretation of the service process:

b) Yoshitake's mixed exponential model may be generalized as a special arrangement of service channel in parallel:

c) Three parameters of the mixed exponential curve can be analytically calculated by using 1). Mean-variance method or 2) Percentage point method:

d) More complex model of service process can be made by using the theory of Markov process, and that

e) These models can de fitted to the actual data for a practical application. 


\title{
病院入院期間の確率論的考察 (梗概)
}

\author{
正会具谷村秀 彦*
}

\section{1.まえがき}

\section{0 病院計画に㧍ける入院期間の意義}

社会福祉の発展に伴い医療施設の整備が，社会全体の 公共的責任として認識されてきている。従来の病院の私 的性格に基いて設けられた病院計画の諸指標は，この観 点から再検討されなければならない。入院期間は，この ように再検討を必要としている指標の一つである。

入院期間（入院日から退院日までの日数，入院日退院 日とも 1 日と数える） $L$, と, 病床数 $B$, 平均 1 日当り新 入院数 $A$, 病床利用率 $u$ との間には次の関係があるこ とはよく知られている。

$$
B=A \times L / u
$$

病院計画の規模算定には，常にこの 3 つの指標を同時 に考慮しなければならないことは，この式に明らかであ る。

\section{1 研究の目的と方法}

本研究の目的は, 病院の入院期間を分析する実用的な 方法を開発することにある。この分野における研究は東 大吉武教授によって進められ既に 1960 年に発表がなさ れているが，この方法は，(1)新入院患者の経日的変動の 影響を受けやすい，(2)分布曲線の近似に主観的判断が入 る, など改良の余地があった。この研究は，入院期間を 確率論的に把えることによってこの方法を改善し, マル コフ過程の理論を適用することによって，理論を一歩前 進させようとする試みである。

\section{2. 理 論}

2.0 序論

ある調査日において， $u$ 日前に新入院し調查日にまだ 在院している患者数を， $u$ 日前のその日に新入院した全 患者数で割った数值は，このグループの入院期間が $u$ 日 以上である確率と考えられる。この数值の分布を $F(x)$, 入院期間の確率分布を $f(x)$ と表わすと, 両者の間には

$$
F(x)=\int_{x}^{\infty} f(x) d x, \int_{0}^{\infty} f(x) d x=1
$$

の関係がある。関数 $f(x)$ は従って確率密度関数, 関数 $F(x)$ は同一現象の確率分布関数である。 $F(x)$ を確率 と考えることによって, 新入院患者数の経日的変動の影 響は除くことができる。平均入院期間は，Fig.-I に示

* University of Manitoba 助教授 （昭和 46 年 7 月 10 日本稿受理・討諭期限昭和 47 年 4 月末日）
す通り， $F(x)$ 曲線の下の面積に等しい。在院患者数が 変動している時には，この方法が最も安定した平均入院 期間の定義と考えられる。

$$
L=\int_{0}^{\infty} x f(x) d x=\int_{0}^{\infty} F(x) d x
$$

\section{1 指数関数モデル}

退院する確率が全くランダムである場合は，入院期間 は次の分布を持つ。

$$
f(x)=\lambda e^{-\lambda x}, F(x)=e^{-i x}, L=\frac{1}{\lambda}
$$

平均入院期間は, パラメーター入の逆数である。いうま でもなく，指数関数はセミログ方眼紙で直線になる。

\section{2 混合指数関数モデル}

ある母集団の中に 2 つ上の性格の異なるグループが 存在する時には，その分布が指数関数の和で表わされる ことがある。このモデルは，Fig.-II b) に示すように， サービス，チャネルの平列配置と考えられる。曲線の近 似は, ガラス，ニュートンの最小二乗法を用いることも できるが，曲線のすその分布が安定していない時はこの 方法では解答が収束しない，代案として次の二通りの方 法が考えられる。

a) 平均一分散法

混合指数関数モデルは次の分布を持つ。

$$
\left.\begin{array}{l}
f(x)=\theta \lambda_{1} e^{-\lambda_{1} x}+(1-\theta) \lambda_{2} e^{-\lambda_{2} x} \\
F(x)=\theta e^{-\lambda_{1} x}+(1-\theta) e^{-\lambda_{2} x}
\end{array}\right\}
$$

観察された $F(x)$ の分布から, 平均入院期間 $L, F(x)$ の平均值 $M, F(x)$ の分散， $V$ を計算する。これらの 数値には, 次の様な関係がある。

$$
\left.\begin{array}{l}
L=\frac{\theta}{\lambda_{1}}+\frac{(1-\theta)}{\lambda_{2}} \\
M=\frac{1}{L}\left(\frac{\theta}{\lambda_{1}{ }^{2}}+\frac{1-\theta}{\lambda_{2}{ }^{2}}\right) \\
V=\frac{2}{L}\left(\frac{\theta}{\lambda_{1}{ }^{3}}+\frac{1-\theta}{\lambda_{2}{ }^{3}}\right)-M^{2}
\end{array}\right\} \begin{aligned}
& \lambda_{1}>\lambda_{2} \\
& .
\end{aligned}
$$

この連立方程式は解があって，1/ $1,1 / \lambda_{2}$ は，二次方 程式

$$
X^{2}-\frac{M^{2}+V-2 L M}{2(M-L)} X^{2}+\frac{L\left(V-M^{2}\right)}{2(M-L)}=0 \cdots
$$

の 2 根である。再分布の割合日 $\theta$ は, 従って

$$
\theta=\left(L-\frac{1}{\lambda_{2}}\right) / \frac{1}{\lambda_{1}}-\frac{1}{\lambda_{2}}
$$

b）パーセント，ポイント法 
任意に $t_{1}$ を選び, 3 点 $t_{1}, t_{2}=2 t_{1}, t_{3}=6 t_{1}$ における 観察值を読み, この 3 点に適合する曲線のパラメーター を推定する。 $p=e^{-\lambda_{1} t_{1}}, q=e^{-\lambda_{2} t_{3}}$ とおくと

$$
\left.\begin{array}{l}
F\left(t_{1}\right)=\theta(p-q)+q \\
F\left(t_{2}\right)=\theta\left(p^{2}-q^{2}\right)+q^{2} \\
F\left(t_{3}\right)=\theta\left(p^{6}-q^{6}\right)+q^{6}
\end{array}\right\}
$$

さらに, $u=p+q, v=p q$ とおくと, 連立式 (9) は解 があって，それは次の様に表わされる。

$$
\left.\begin{array}{l}
\theta=\frac{F\left(t_{1}\right)-q}{p-q} \\
v=F\left(t_{1}\right) u-F\left(t_{2}\right) \\
u^{4}-2 F\left(t_{1}\right) u^{3}+3 F\left(t_{2}\right) u^{2}=\frac{F\left(t_{3}\right)-F\left(t_{2}\right)^{3}}{F\left(t_{2}\right)-F\left(t_{1}\right)^{2}}
\end{array}\right\}
$$

\section{3 エアラング関数モデル}

分布の偏差が全くのランダム以下である場合の分布 は，エアラング関数で表わされることがある。このモデ ルは, Fig.-II c) のようにサービス, チャネルの直列配 置と考えられる。チャネルの数を整数 $k=1,2,3$ と寸る と, この分布は

$$
\begin{aligned}
& f(x)=\rho(\rho x)^{k-1} \frac{e^{-\rho x}}{(k-1) !} \\
& F(x)=\sum_{r=0}^{k-1} \frac{e^{-\rho x}(\rho x)^{r}}{r !} \\
& L=\frac{k}{\rho}
\end{aligned}
$$

で表わされる。

\section{4 マルコフ過程モデル}

上記の混合指数関数モデル，エアラング関数 モデル は, 単純指数モデルの 1 次元的な配置一平列と直列一で あるが，マルコフ過程の理論を用いてもっと複雑な多次 元的配置を考えることが可能である。ここでは，Fig.II の d) に示す 4-States のマルコフ過程をモデルと する。4つの状態は次の様に定義される。

1. 入院直後の積極的治療

2. 1. の後の短期療養

3. 1. の後の長期療盖

4. 死亡または退院

State $i$ から State $j$ への Transition rate $r_{i j}$ と すると，このマルコフ過程はマトリックス

$$
\boldsymbol{Q}=\left(\begin{array}{cccc}
r_{11} & r_{12} & r_{13} & 0 \\
0 & r_{22} & 0 & r_{24} \\
0 & 0 & r_{33} & r_{34} \\
0 & 0 & 0 & 0
\end{array}\right)
$$

で定義される。特別の場合として $r_{11}=-\lambda_{1}, r_{12}=\theta \lambda_{1}$, $r_{13}=(1-\theta) \lambda_{1}, r_{22}=-\lambda_{1}, r_{24}=\lambda_{1}, r_{33}=-\lambda_{2}, r_{34}=\lambda_{2}$ を以 下考察する。(行の総和は常に 0 , また $\lambda_{1} \neq \lambda_{2}$ )

$1,2,4$ と進むルートの入院期間分布のラプラース変 換は，

$$
f_{1}^{*}(s)=\left(\frac{\lambda_{1}}{\lambda_{1}+s}\right)^{2}
$$

同じく, 1, 3, 4 と進むルートのラプラース変換は

$$
f_{2}^{*}(s)=\left(\frac{\lambda_{1}}{\lambda_{1}+s}\right)\left(\frac{\lambda_{2}}{\lambda_{2}+s}\right)
$$

従って, 全体入院期間の密度分布のラプラース変換は

$$
f^{*}(s)=\theta\left(\frac{\lambda_{1}}{\lambda_{1}+s}\right)^{2}+(1-\theta)\left(\frac{\lambda_{1}}{\lambda_{1}+s}\right)\left(\frac{\lambda_{2}}{\lambda_{2}+s}\right) \cdots
$$

すなわち，入院期間の分布は次の通りとなる。

$$
\left.\begin{array}{l}
f(x)=\theta \lambda_{1}{ }^{2} x e^{-\lambda_{1} x}+(1-\theta) \frac{\lambda_{1} \lambda_{2}\left(e^{-\lambda_{2} x}-e^{-\lambda_{1} x}\right)}{\lambda_{1}-\lambda_{2}} \\
F(x)=\theta\left(1+\lambda_{1} x\right) e^{-\lambda_{1} x}+(1-\theta) \frac{\lambda_{1} e^{-\lambda_{2} x}-\lambda_{2} e^{-\lambda_{1} x}}{\lambda_{1}-\lambda_{2}} \\
L=\frac{2 \theta}{\lambda_{1}}+(1-\theta) \frac{\lambda_{1}+\lambda_{2}}{\lambda_{1} \lambda_{2}}
\end{array}\right\}
$$

\section{3. 適用}

3.0 混合指数関数モデル

松本啓俊氏の好意により，1966 年に氏が発表された 労災病院の在院期間分布の原資料 (学論 No. 124) が利

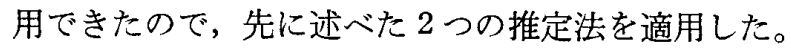

a) 平均一分散法

原資料から $L=336.7, M=535.6, V=286,852.4$ を 計算し，式 (6)，(7) を用いて Table I に示される数 值を得た。新入院患者数変動は原資料に含まれていない ので, 平均值 385 人/50 日を用いた。

b) パーセント・ポイント法

75 日, 150 日， 450 日の 3 点の数值を読み, この 3 点に合う曲線を式 (9)，(10) 加ら求めた。

適合度を比較するために，350日までと，全体の 2 種 のカイ自乗を表に示すように算定した。パーセント・ポ イント法は, もちろん, 選択した点の近くでよく適合し, 平均一分散法は全体としてょく適合している。松本氏の 推定を含めて Table I, Fig.-III に結果を示した。

\section{1 エアラング関数モデル}

東京病院（元東療清瀬）の 1970 年 10 月 21 日にお ける在院患者 1,200 人の入院日と, 1963 年までの 新 入院患者数変動が, 吉武教授および磯村, 横掘両氏の御 好意により入手できたので，このモデルの適合性をテス トした。 $k=2$ とし，平均值をあわせた分布をTable-II, Fig.-IV に示寸。入院期間 3 年のあたりから，エアラ ング関数は観察值と著るしく違ってくる。

\section{2 マルコフ過程モデル}

上記の結果より，この資料はエアラングと混合指数の コンビネーションとみられそうなのでマルコフ過程モデ ルを適用した。吉武教授の 1962 年の発表にあるように （学論 No. 71）, 短期 1 年, 長期 5 年の 2 グループを考 え，それぞれ 6 か月， 6 か月，54 か月の平均滞在期間 を State 1, State 2, State 3 に対して想定し, 平均入 院期間が観察值と合致するよう $\theta$ を定め，数值を計算し た。結果は, Table-II, Fig.-IV に示すごとく，非常に 良好でこのモデルが極めて実際現象と近いことを示す。 


\title{
COST STUDY OF STRUCTURAL FRAME FOR SCHOOL BUILDINGS
}

(Part II)

\author{
Prefabricated School Buildings -
}

by AKIO MATSUMOTO, Member of A.I.J.

\begin{abstract}
A comparative study of the economy and the labor on-site of ALC (Autoclaved Lightweight Concrete) curtain wall system, HPC (Hshaped steel and precast concrete pannel) system and PC (precast concrete) pannel system, which are suitable for the prefabricated school systems, are made with brief structural calculations and cost estimates.

If 4-story schools are compared, the PC pannel system is $20 \%$ more expensive in comparison to the conventional concrete construction. And the ALC curtain wall system and the HPC system are approximately twice as much as the conventional method, The unit of labor on site, however, will be less in an order the conventional method, the ALC curtain wall system, the HPC systr $m$ which is most prefabricated; therefore saves $35 \%$ labor on site in comparison to the conventional method.

With the change of education system which is apparant, the space and the use of classrooms will eventually change from the present standard. Rather than designing fixed classrooms whith the antiseismic wall like Type I free open classrooms like Type II will be more adaptable to the future education.

From the educational and structural points of view, it is worse push forward the application of the ALC curtain wall system and the HPC systems of Type II as the future school building structures rather than cheaper PC pannel system of Type I.
\end{abstract}

U.D.C. 725.51 .011 .1

A PROBABILISTIC ANALYSIS OF LENGTH OF STAY IN hOSPITAL

(See Page 75)

HIDEHIKO TANIMURA

Assistant Professor Department of City Planning University of

Manitoba, Member of A.I.J.

U.D.C. 64.01

\section{A STUDY ON MAN-SPACE SYSTEM}

by RIYOZO NAKAMURA. HIROSHI WATANABE, HIROYUKI NAITOU, Graduate Student Univ of Waseda YOSHIROU

IKEHARA, Prof of Univ of Waseda, Members of A.I.J.

We have been studying human-space systems and have already conducted surveys, analyzed our data, and made predictions. The purpose of this part of our study, the fourth, is to attempt to deal with problems of systems evaluation.

The study has been conducted to identify inherent human factors affecting behavior in the space of the $T$ Amusement Park; to establish some standard of value for these factors in our system through quantification; to thence evaluate human behavior; and finally, by feeding our findings back into the spatial plan, to make the human-space relationship a moer human as well as a more scientific one. 